Anna Trosborg*

\title{
Regulative Strategies in Arbitration Law Uncitral Model Law on International Commercial Arbitration (UNCITRAL) compared with Arbitration Law of the People's Republic of China
}

\begin{abstract}
This paper is concerned with the laying down of the law in international and domestic arbitration. Interest centres on regulative and constitutive functions, and an analysis of realisation patterns of regulative (directive) acts is reported. The focus is on the linguistic realisation patterns of obligation, prohibition, and permission in terms of modal verbs and constitutive rules.

The findings show that the language of the law characteristically select patterns of directives which are specific to the legal domain. Face redress typically used in everyday communication as well as business interaction is not a device used in arbitration law. Moreover, the linguistic devices employed differ as regards different parts of the law. Modal verbs are typically applied for action rules, whereas constitutive rules are mainly reserved for stipulation rules and definition rules.

The analysis offers a comparison of Unicitral Model Law and domestic law. Finally, attention is paid to the adequacy of the chosen linguistic realisation patterns as regards simplification/ easification of legal expressions. The results are compared to those obtained in a previous study of Contract Law.
\end{abstract}

\section{Introduction}

Many of the difficulties lay persons are confronted with when comprehending legal written texts are due to syntactic complexity, such as sentence length and use of nominalisations, a high frequency of passive

\footnotetext{
* Anna Trosborg

The Aarhus School of Business

Department of English

Fuglesangs Allé 4

DK-8210 Aarhus V
} 
100

sentences, the use of complex conditionals and a high incidence of prepositional phrases (see Trosborg 1997: 14 for references).

Another source of difficulty is lexical complexity. Legal vocabulary exhibits distinctive features particular to expressing the concepts of law. Characteristic of the legal register are technical terms, common terms with uncommon meanings, archaic expressions, and formal items (see Danet 1985: 279-80). It is no wonder then that many studies of legal language have been concerned with syntactic and lexical features. For a very recent study of these aspects in Arbitration Law, see Engberg and Rasmussen (2003).

However, another area which has been of growing interest in the study of legal genres is pragmatics (see e.g. Gunnarsson 1984; Kurzon 1986; Bowers 1989). One aspect of particular salience is communicative acts (or rhetorical functions to use Trimble's 1985 term) of legal English. Bowers (1989) has described the field of a statute as follows:

The field of a statute is that of a real social action which carries the whole weight of law in that it is constitutionally authorized. A public statute, whether it is declaratory, remedial, codifying, enabling, or penal is concerned with the conduct of social affairs and the granting of permissions or the imposing of obligations on members of the society (Bowers 1989: 53, also quoted in Trosborg 1997: 27).

As pointed out by Kurzon (1989: 288), very little work has been done in this field. To fill this gap, Trosborg (1997) undertook a study of the genres of statutes and contracts in the domain of Contract Law focussing on communicative acts (speech acts) intended to modify/regulate social behaviour.

In the present paper, this approach is extended to the domain of Arbitration Law. It analyses the regulative acts in Uncitral Model Law on International Commercial Arbitration with those observed in Arbitration Law of the People's Republic of China. The purpose is to identify the regulative strategies fundamental to laying down the law in the domain of international arbitration and to establish their relative frequencies in Chinese Law in comparison with Uncitral Model Law.

The UNCITRAL Model Law on International Commercial Arbitration was adopted by the United Nations Commission on International Trade Law (UNCITRAL) on 21 June 1985, at the close of the Commission's annual session. In its resolution 40/72 of 11 December 1985, The General Assembly recommended "that all States give due consideration 
to the Model Law of International Commercial Arbitration, in view of the desirability of uniformity of the law of arbitral procedures and the specific needs of international commercial arbitration practice" UNCITRAL p. 14).

The model law is "designed to meet concerns relating to the current state of national laws on arbitration. The need for improvement and harmonization is based on findings that domestic laws are often inappropriate for international cases and that considerable disparity exists between them" (UNCITRAL p. 14).

The Arbitration Law of the People's Republic of China (ALPRC) was adopted at the Ninth Standing Committee Session of the Eighth National People's Congress on August 31, 1994.

\section{Regulative acts in arbitration law}

The laying down of the law is a declaration. In national law each statute is preceded by an enacting formula, for example, the so-called promulgation formula found in British statutes:

"BE IT ENACTED by the Queen's most Excellent Majesty, by and with the advice and consent of the Lords Spiritual and Temporal, and Commons, in this present Parliament assembled, and by the authority of the same, as follows: (Minors' Contract Law, quoted in Trosborg 1997: 34).

In the arbitration laws in question, no such enacting formula was observed. Neither was there any use of performative verbs, such as declare (British English) or authorize, entitle and amend to be found in American statutes (Kurzon 1989: 24).

There are three types of legislative rules (Gunnarsson 1984: 84, quoted in Bhatia 1994: 138-139):

Action rules are applicable to only a set of specified descriptions of cases and are mainly meant to impose duties and obligations, to give rights, to prohibit actions, to assign power to certain members of bodies of the executive or other parties, or to state the law or just the penalties imposed on specific actions.

Stipulation rules define the domain of application of a particular act or any section of it.

Definition rules are applicable to the entire Act and are primarily meant to provide terminological explanation. 
The regulation of behaviour in the laws examined was carried out by means of conferring rights, imposing obligations, stating prohibitions and outlining constitutive rules. These functions are described and exemplified in the following.

\subsection{Permission}

In legislation, permission issues from authority. The legislature grants permission to the body in question to perform certain acts; it does not order the body to do so, as is the case of statements of obligation. In Arbitration Law, statements of permission serve to establish the rights of the arbitral tribunal and the parties of the conflict. A typical rhetorical strategy is the use of the modal may, which functions as an indirect performative, as in the following examples:

The arbitral tribunal may rule on its own jurisdiction, including any objection with respect to the existence in validity of the arbitration agreement. (p. 7)

The arbitral tribunal may require any party to provide appropriate security in connection with such measure. (p. 7)

If the arbitral tribunal rules as a preliminary question that it has jurisdiction, any party may request, within thirty days after having received notice of that ruling, the court specified in article 6 to decide the matter, which decision shall be subject to no appeal. (p. 7)

May is the predominant illocutionary device used when conferring rights. A few examples made use of the expression be free to:

The parties are free to determine the number of arbitrators. (p. 5)

The parties are free to agree on a procedure of appointing the arbitrator or arbitrators, subject to the provisions of paragraph (4) and (5) of this article. (p. 5)

Even the expression grants freedom to was observed:

It grants the parties the freedom to choose the applicable substantive law, which is important in view of the fact that the number of national laws do not clearly or fully recognize that right. (p. 19)

Furthermore, may also occurred in examples where the act of permission is dubious:

An arbitration agreement may be in the form of an arbitration clause in a contract or in the form of a separate agreement. (p. 4) 
Such statements belong to the category of stipulation rules and are better classified as constitutive rules.

The verbs could and need not were each observed only once in the UNCITRAL data:

As regards the term "commercial", no hard and fast definition could be provided. (p. 15)

... the award need not be signed by the arbitrators at the same place. (p. 20)

Here the function is that of definition and stipulation, respectively. In ALPRC there was one instance in which the modal can was used to express possibility:

If..., a ruling can be made by default. (p. 7)

Can was not used to regulate behaviour in UNCITRAL.

\subsection{Obligation}

Statements of obligation used to regulate behaviour have the illocutionary force of orders. Only one instance employing the performative verb oblige was found:

Modelled on article II(3) of the 1958 New York Convention, article $8(1)$ of the Model Law obliges any court to refer the parties to arbitration if seized with a claim on the subject matter unless it finds that the arbitration agreement is null and void, inoperative or incapable of being performed. (p. 17)

Typically the modal shall expresses obligation in legal acts. This use of shall, referred to as "mandatory shall" is not only endowed with the meaning that the subject shall do X, it also carries the implication that if he/she doesn't, there will be sanctions. Examples of shall to impose obligation are:

The arbitral tribunal shall decide the dispute in accordance with such rules of law as are chosen by the parties as applicable to the substance of the dispute. (p. 10)

If, during arbitral proceedings, the parties settle the dispute, the arbitral tribunal shall terminate the proceedings, and, if requested by the parties and not objected to by the arbitral tribunal, record the settlement in the form of an arbitral award on agreed terms. (p. 10) 
Statements of obligation may be in the active voice as above, or they can take the form of passive constructions:

The parties shall be treated with equality and each party shall be given a full opportunity of presenting the case. (p. 8)

The award shall be made in writing and shall be signed by the arbitrator or arbitrators. (p. 10)

A number of statements employing the modal shall were not used to impose obligation but rather had the function of stipulation rules. These are listed and exemplified under constitutive rules.

The modals must and have to are typically used to express obligation in conversational English, but in legal contexts they are rarely observed. Must did not occur in ALPRC at all, and it was observed only three times in UNCITRAL:

An application for setting aside under article 34 must be made within three months of receipt of the award. (p. 20)

The award must be in writing and state its date. It must also state the reasons on which it is based, unless the parties have agreed otherwise or the award is an award on agreed terms,... (p. 20)

The verb have to occurred in neither.

Other modals expressing obligation are should, ought to and need. Whereas ought to was not observed at all, the modal should occurred three times in UNCITRAL and three times in ALPRC:

It should be noted that article 24(1) deals only with the general right of a party to oral hearings... and not with the procedural aspects such as length, number or timing of hearings. (p. 18)

The term "commercial" should be given a wide interpretation. (p. 3)

These instances are listed in article 6 as functions which should be entrusted ...to a specially designed court or ... (p. 16)

It should be noted is a fixed phrase and the two other examples express stipulation rules.

In ALPRC, the modal should occurred in examples like the following:

The arbitration commission director shall decide whether an arbitrator should withdraw... (p. 6)

The arbitration tribunal may also decide on its own whether the ongoing arbitration process should be started anew. (6) 
The modals should and ought to are "weak" indicators of obligation, which explains their infrequent use in Arbitration Law.

The modals will and would were not observed in ALPRC, whereas will occurred three times and would four times in UNCITRAL, both with the function of stipulation or prediction:

The vast majority of situations commonly regarded as international will fall under this criterion. (p. 15)

... but guarantees the reader and user that he will find all instances of possible court intervention, except for matters not regulated by it ... (p. 16)

Especially foreign readers and users, who constitute the majority of potential users and may be viewed as the primary addressees of any special law on international commercial arbitration, will appreciate that they do not have to search outside this Law. (p. 16)

The conditions set forth in this paragraph are intended to set maximum standards. It would, thus, not be contrary to the harmonization to be achieved by the model law if a State retained even less onerous conditions. (p. 13)

It is advisable to follow the model as closely as possible since that would be the best contribution to the desired harmonization and in the best interest of the users of international arbitration, who are primarily foreign parties and their lawyers. (p. 14)

According to article 1(2), the Model Law as enacted in a given State would apply only if the place of arbitration is in the territory of that State. (p. 16)

Insofar as... the provision would apply irrespective of whether the request is made to a court of the given State or of any other country. (p. 17)

So far, it appears that only the modal shall is used to impose obligations on people. When the other modals with regulative meaning occur, they are mainly used to express stipulation rules. Insofar as these modals were infrequent in use, anyhow, in Arbitration Law, they are listed under obligation and not in a separate category. With regard to the use of legal shall, the predominant function was regulation in action rules. There were, however, a substantial number of shall's which were used to define domain of application or even to provide terminological explanations. These are analysed as a separate category of constitutive rules. 


\subsection{Prohibition}

The regulation of behaviour can also take place by issuing prohibitions, but this device is infrequent in use compared with statements of obligation. Prohibition is used in examples like "No person shall..."; "No court shall...". Additionally, shall + negation is used to state rules according to which a given law operates:

In matters governed by this Law, no court shall intervene except where so provided in this Law. (p. 4)

This law shall not affect any other law of this State by virtue of which certain disputes may not be submitted to arbitration or may be submitted to arbitration only according to provisions other than those of this Law. (p. 3)

\subsection{Constitutive rules}

Statements which do not include performative verbs, or modals which function as implicit performatives, may still serve the purpose of regulating behaviour. This applies to English legislative texts as well as conversational English.

Sentences used to explain or define expressions and words in the statute or to supply information concerning the application of the statute, or part of it, are constitutive rules (Kurzon 1986: 23). In UNCITRAL and ALPRC, unmarked statements outlined constitutive rules concerning definition rules and stipulation rules. A typical indicator of definition rules is the verb mean, but also words such as define, constitute, and be are found:

"arbitration" means any arbitration whether or not administered by a permanent arbitral institution;

"arbitral tribunal" means a sole arbitrator or a panel of arbitrators;

"court" means a body or organ of the judicial system of a State; (p. 3)

The model Law defines an arbitration as international if "the parties to an arbitration agreement have, at the time of the conclusion of that agreement, their places of business in different States" (article 1 (3)). (p. 15)

"Arbitration agreement" is an agreement by the parties to submit to arbitration all or certain disputes which have arisen or which may 
arise between them in respect of a defined legal relationship, whether contractual or not. (p. 4)

The reference in a contract to a document containing an arbitration clause constitutes an arbitration agreement provided that... (p. 5)

A typical indicator of stipulation rules is the verb apply; other indicators are have, include, be deemed to, be intended to, ensure:

This Law applies to international commercial arbitration, subject to any agreement in force between this State and any other State or States. (p. 2)

If..., an arbitrator withdraws from his office or a party agrees to the termination of the mandate or of an arbitrator, this does not imply acceptance of the validity of any ground referred to in this article or article (12(2). (p. 7)

Such an award has the same status and effect as any other award on the merits of the case. (p. 10)

... such agreement includes any arbitration rules referred to in that agreement; (p. 3)

Any written document is deemed to have been received if it is delivered to the addressee personally or it is delivered at his place of business, habitual residence or mailing address. (p. 4)

... his mandate terminates, if he withdraws from his office or if the parties agree on the termination. (p. 6)

The conditions set forth in this paragraph are intended to set maximum standards. (p. 13)

... the Model Law ensures, by providing a set of suppletive rules, that the arbitration may commence and proceed effectively to the resolution of the dispute. (p. 17)

Other verbs observed in constitutive statements are: is given, exists, envisages, is stated, guarantees, deals with, follows closely, recognizes, expresses, etc. There is no sharply defined distinction between definition rules and stipulation rules. Furthermore, many rules classified as constitutive rules go far beyond definition and stipulation and are part of the law per se regulating people's behaviour.

A special category of constitutive rules are those involving the modal shall. Here we find that the typical indicator of obligation in action rules is in fact also used in stipulation rules: 
The award shall state the reasons on which it is based, unless the parties have agreed that no reasons are to be given or the award is an award on agreed terms under article 30. (p. 10)

The award shall be deemed to have been made at that place. (p. 10)

The interpretation shall form part of the award. (p. 11)

The provisions of article 31 shall apply to a correction or interpretation of the award or to an additional award. (p. 11)

... which decision shall be subject to no appeal. (p. 7)

This agreement or determination, unless otherwise specified therein, shall apply to any written statement by a party, any hearing and any award, decision or other communication by the arbitral tribunal. (p. 8)

In arbitral proceedings with more than one arbitrator, the signatures of the majority of all members of the arbitral tribunal shall suffice, provided that the reason for any omitted signature is stated. (p. 11)

\section{Results and Discussion}

The individual results of the analyses appears in Table 1 for UNCITRAL and Table 2 for ALPRC, and Table 3 shows the comparison of the two. 


\begin{tabular}{|c|c|c|}
\hline \multicolumn{3}{|c|}{ Regulative Acts in Uncitral Model Law on International Commercial Arbitration } \\
\hline $\begin{array}{l}\text { Cat. I Constitutive rules } \\
\quad \text { (unmarked strategies) } \\
\text { shall }\end{array}$ & $\begin{array}{r}38.7 \\
6.5\end{array}$ & 45.2 \\
\hline $\begin{array}{l}\text { Cat. II Permission (rights) } \\
\text { be free to } \\
\text { may } \\
\text { need not } \\
\quad \text { could }\end{array}$ & $\begin{array}{r}1.2 \\
19.8 \\
0.4 \\
0.4\end{array}$ & 21.8 \\
\hline $\begin{array}{l}\text { Cat. III Obligation } \\
\text { Oblige } \\
\text { shall } \\
\text { will } \\
\text { would } \\
\text { should } \\
\text { must }\end{array}$ & $\begin{array}{r}0.4 \\
25.3 \\
1.2 \\
1.5 \\
1.1 \\
1.1\end{array}$ & 30.6 \\
\hline $\begin{array}{l}\text { Cat. IV Prohibition } \\
\text { shall not } \\
\text { may not }\end{array}$ & $\begin{array}{l}1.2 \\
0.8\end{array}$ & 2.0 \\
\hline
\end{tabular}

Table 1

\begin{tabular}{|c|c|c|}
\hline \multicolumn{3}{|c|}{ Regulative Acts in Arbitration Law of the People's Republic of China } \\
\hline $\begin{array}{l}\text { Cat. I Constitutive rules } \\
\text { (unmarked strategies) } \\
\text { shall }\end{array}$ & $\begin{array}{r}11.7 \\
9.9\end{array}$ & 21.6 \\
\hline $\begin{array}{l}\text { Cat. II Permission (rights } \\
\text { may } \\
\text { can }\end{array}$ & $\begin{array}{r}22.2 \\
0.6\end{array}$ & 22.8 \\
\hline $\begin{array}{l}\text { Cat. III Obligation } \\
\text { shall } \\
\text { should }\end{array}$ & $\begin{array}{r}51.2 \\
1.9\end{array}$ & 53.1 \\
\hline $\begin{array}{l}\text { Cat. IV Prohibition } \\
\text { shall not } \\
\text { may not }\end{array}$ & $\begin{array}{l}1.9 \\
0.6\end{array}$ & 2.5 \\
\hline
\end{tabular}

Table 2 
110

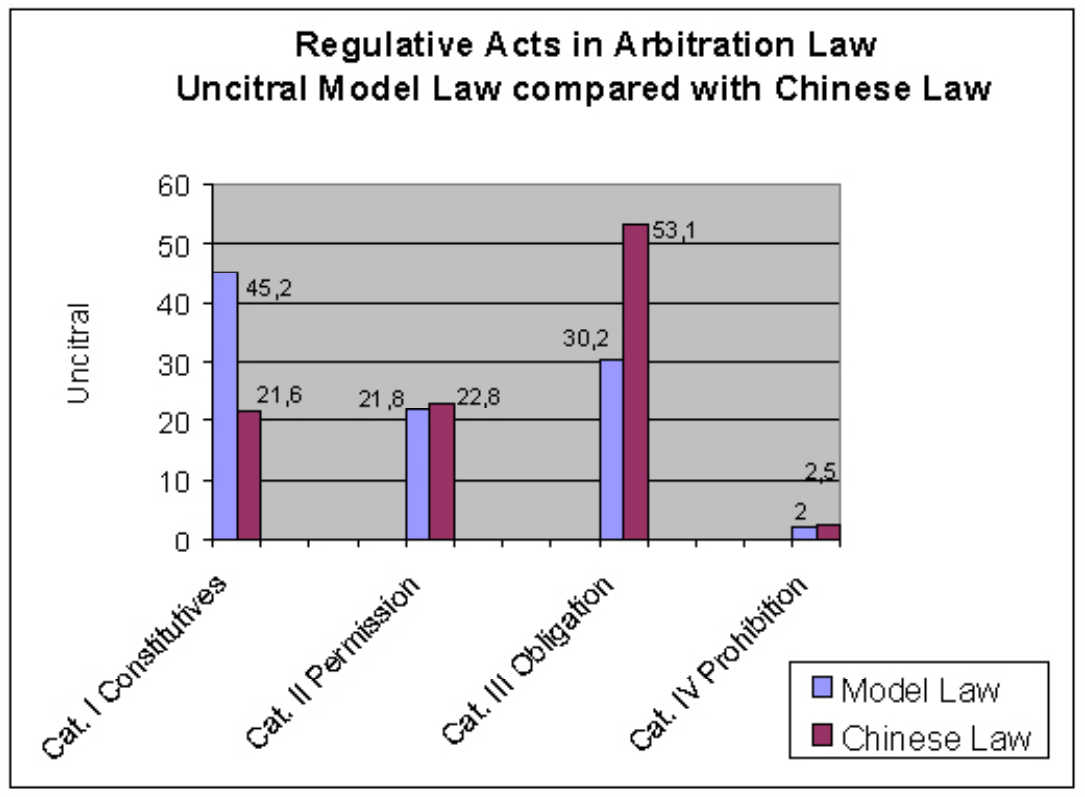

Table 3

As it is shown in Table 3, the findings for the two laws are very similar on Cat. II Permission statements $(21.8 \%$ vs. $22.8 \%)$, amounting to a little above $1 / 5$ of all strategies employed. The results are also very similar for Cat. IV Prohibition, which was very low on both laws $(2.0 \%$ vs. $2.5 \%$ ). However, when looking at Cat. III Obligation, it is apparent that strategies imposing obligation are the most frequent strategy used in ALPRC amounting to more than half the strategies used (53.1\%). In comparison, UNCITRAL only has $30.2 \%$ strategies in this category. For Cat. I Constitutive rules, it is the other way round. These strategies are used in UNICITRAL with a frequency of $45.2 \%$ compared with only $21.6 \%$ in ALPRC. These findings need to be explained.

As regards Cat. III Obligation, UNCITRAL employed the widest range of modals (shall, must, will, would, should) even though it had the lowest score on this category, whereas ALPRC mainly employed mandatory shall (51.2\%) (see Tables 1 and 2). This points to a predominance of the use of shall in ALPRC. This tendency is also evident in Cat. I Constitutive rules, where ALPRC employs shall in $9.9 \%$ of the 
strategies used in comparison with $6.5 \%$ in UNCITRAL. This finding is observed despite the fact that as a total UNCITRAL has the double number of constitutives compared with ALPRC.

There is then less variety in the use of strategies (modals as well as constitutive rules) in ALPRC compared with UNCITRAL. This points to a "playing-it-safe" strategy used in ALPRC with the modal shall as the predominant marker in regulative acts.

To allow for a comparison of the results of the analysis of regulation in UNCITRAL with those obtained for Contract Law (Trosborg 1977), Table 4 shows the individual results of Contract Law and Table 5 compares the two laws.

\begin{tabular}{|lcc|}
\hline \multicolumn{2}{|c|}{ Regulative Acts in English Statutes (Contract Law) } \\
\hline Cat. I Constitutive rules \\
(unmarked strategies) \\
shall & 39.3 & \\
are to & 14.5 & 60.9 \\
\hline Cat. II Permission (rights) & 7.1 & \\
May & 8.9 & 8.9 \\
\hline Cat. III Obligation & & \\
Performatives & 1.2 & \\
Shall & 6.9 & 17.5 \\
should/ought to & 3.0 & \\
other & 6.4 & 11.9 \\
\hline Cat. IV Prohibition & & \\
Cannot & 8.3 & \\
shall not & 3.6 & \\
\hline
\end{tabular}

Table 4 


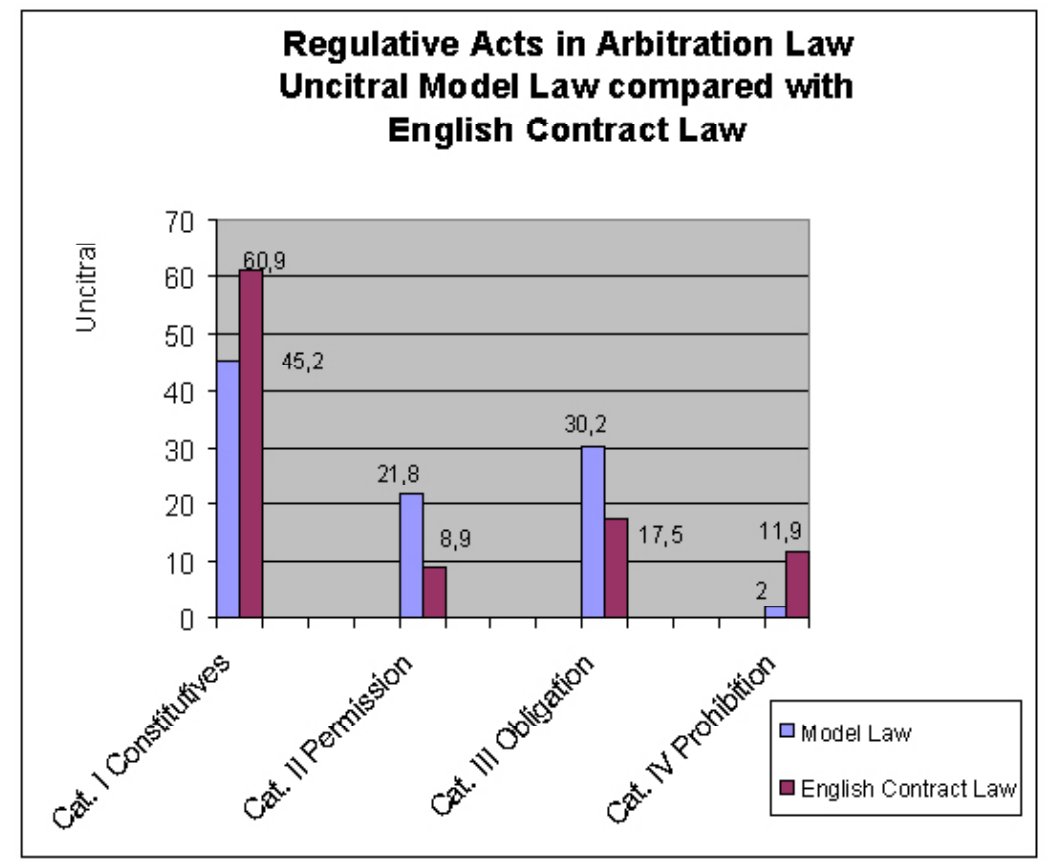

Table 5

The predominance of Constitutive rules is even greater here. In Contract law, this category amounts to $60.9 \%$ compared with $45.2 \%$ in UNCITRAL. Mandatory shall is used only with a frequency of $6.9 \%$ against $25.3 \%$ in UNCITRAL. This points towards an increase in the use of mandatory shall across the three kinds of law counterbalanced by a decrease in the use of constitutive rules.

With regard to the use of legal shall in constitutive rules, a decrease was observed from Contract Law to UNCITRAL (14.5\% vs. $6.5 \%)$. There was, however, an increase on this category when the findings of ALPRC was compared with those of UNCITRAL (9.5\% vs. $6.5 \%$ ).

The corpus of Contract Law included laws written between 1960 and 1987, whereas UNCITRAL dates from 1985 and ALPRC from 1994. The time factor may have played a role in the selection of regulative strategies. The findings point towards a shift away from a predominance of constitutive rules observed in both Contract Law and UNCITRAL to a predominance of legal shall in ALPRC. 
The use of shall in constitutive rules needs to be commented on, as it has been criticised by a number of researchers. Bowers (1989) finds that shall is inappropriate in expressions where there is no agent. Stipulations of the kind it shall be lawful and it shall de deemed should be in the modal-less form of statements - simply it is lawful and it is deemed. Thus legal shall should be avoided in constitutive rules and in regulatives where no agent is present in explicit form or recoverable from context. The use of shall as the appropriate expression of a regulative with agent (explicit or recoverable) is recommended by Child (1992). At the same time she warns against the use of shall to express constitutive rules (referred to by her as "future tense"). She has emphasized the importance of "saving" shall for orders, and warns against the misuse of shall referred to as the "false imperative".

\footnotetext{
Shall is the most powerful word in the legislative arsenal. It must not be squandered by misuse. Shall must not be wasted by being used to put verbs in the future tense. The future tense is seldom needed in statutes for a legislative act applies to the everpresent present. (Child 1992: 205, quoted in Trosborg 1997: 137)
}

As an example of a false imperative, she mentions "It shall be a felony to commit murder". Assuming that the law is presently in effect, the accurate phrasing is: "It is a felony to commit murder".

According to Child, overuse of shall is a common error among novice drafters. They find it unnatural to write in the present tense while thinking of the future. The drafter must learn to think in terms of the time when the statute is read. If this is done, the present tense comes easily and "those invaluable shalls are saved for their proper use" (to give an order).

A comment is needed regarding the use of the modal must. In 1989, Eagleson writes that some lawyers are now moving to replace shall with must in their documents when an obligation is being imposed or mandatory conduct is prescribed (p. 76). This claim is made to avoid confusion for the clients (not familiar with "legal shall") who would be likely to interpret shall as expressing mere futurity. The urge to use must is supported by e.g. Bennet (1989) and Elliott (1990), whereas, for example, Child (1992) argues against the use of must to impose obligation.

The use of must to express obligation was not observed in Contract Law, neither was it found in ALPRC, and it was only used with a low 
frequency in UNCITRAL (1.1\%). Thus the recommendation to use must to the exclusion of mandatory shall has not gained ground in legal drafting.

Finally, there was an increase in ALPRC compared with UNCITRAL in the use of legal shall to the exclusion of other modals, and of unmarked constitutive rules, in particular. As mentioned, this can be explained as a strategy of "playing it safe". Drafters adhere to the powerful force of legal shall and tend to overuse it even in constitutive rules.

\section{References}

Bennet, E. 1989: In defence of "shall". The Australian Law Journal, vol. 63.

Bhatia, Vijay 1994. Cognitive structuring in legislative provisions. In John Gibbons (ed.) Language and the Law. Harlow: Longman, 136-155.

Bowers, Frederick 1989: Linguistic Aspects of Legislative Expression. Vancouver: University of British Columbia Press.

Child, Barbara 1992: Drafting Legal Documents: Principles and practices. American Casebook Series. St. Paul, Minn.: West Publishing Co.

Danet, Brenda 1985: Legal discourse. In Handbook of Discourse Analysis, vol. 1, ch. II. London: Academic Press.

Eagleson, Robert 1989: Current topics. The Australian Law Journal.

Elliott, David 1990: Legal drafting: Language and the Law. Canadian Institute for the Administration of Justice, Ottowa.

Engberg, Jan/Rasmussen, Kirsten Wølch 2003. Danish legal language in international commercial arbitration: A comparison of the Geneva Convention and the Danish Statutory Text incorporating its rules in Danish law. In Bhatia, Vijay/Candlin, Christopher N./Gotti, Maurizio (eds.): Legal Discourse in Multilingual and Multicultural Contexts: Arbitration texts in Europe. Bern et al. 2003: Lang.

Gunnarsson, Britt-Louise 1984. Functional comprehensibility of legislative texts. In TEXT 4-1/3: 71-105.

Kurzon, Dennis 1986: It is hereby Performed... Explorations in Legal Speech Acts. Pragmatics and beyond, v. VII:6. Amsterdam/Philadelphia: John Benjamins Publishing Company.

Kurzon, Dennis 1989: Language of the law and legal language. In Laurén Christer/ Nordman, Marianne (eds.): Special Language: From humans thinking to thinking machines. Multilingual Matters: Clevedon/Philadelphia.

Trimble, Louis 1985: The rhetoric of EST discourse. In Louis Trimble, English for Science and Technology. A discourse approach. Cambridge: Cambridge University Press, 10-21. 
Trosborg, Anna 1997: Rhetorical Strategies in Legal Language. Discourse analysis of statutes and contracts. Tübingen: Gunter Narr Verlag. 


\title{
Add dimension to your sociological research
}

\section{sofiological abstracts}

\author{
Comprehensive, cost-effective, timely
}

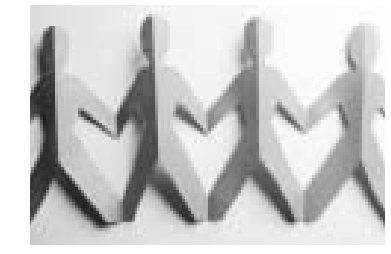

Abstracts of articles, books, and conference papers from nearly 2,500 journals published in 35 countries; citations of relevant dissertations as well as books and other media.

Available in print or electronically through the Internet Database Service from Cambridge Scientific Abstracts (www.csa.com).

Contactsales@csa.com for trial Internet access or a sample issue.

\section{sociological abstracts}

\author{
Published by CSA
}

